\title{
Association of ACE Gene Polymorphisms with Coronary Artery Disease in a Northern Area of Japan
}

\author{
Kentaro Takahashi, M.D., Hidenori Nakamura, M.D., \\ Isao Kubota, M.D., Noriko TaKahashi, M.D., \\ and Hitonobu Tomorke, M.D.
}

\begin{abstract}
SUMMary
The insertion/deletion DNA polymorphism of the gene coding human angiotensin converting enzyme (ACE) was examined in 109 patients with coronary artery discase $(\mathrm{CAD})$ and 93 non-coronary subjects (NCS) living in a northern part of Japan. The presence of risk factors including age, hypertension, hypercholesterolemia, tobacco use, diabetes mellitus and hyperuricemia were also examined. An insertion (I) / deletion (D) polymorphism of the ACEgene was determined by the polymerase chain reaction with oligonucleotide primers encompassing the polymorphic region in intron 16. The template DNA was isolated from peripheral blood leukocytes of patients. The frequency of the D-allele in NCS was 0.27 , significantly lower than that reported in Caucasians or in Japanese living in the Osaka area. The frequency of the Dallele in patients with myocardial infarction (MI) and angina pectoris was 0.39 and was higher than that in NCS. The frequencies of genotypes DD, ID, and II were $17.8,43.3$ and $38.9 \%$, respectively, in CAD except in young patients (below 40 years of age) with MI and AP groups, and 6.5, 40.9 and $52.7 \%$, respectively in NCS $(p<0.05$ between CAD and NCS). Young MI showed similar frequencies in ACE gene polymorphisms to those in NCS, a pattern which differed from that seen in subjects with CAD $(p<0.05)$. The numbers of risk factors did not alter the frequency of ACE gene genotype among patients with $\mathrm{CAD}$, however, in normotensives, the odds ratio of DD-genotype was significantly increased to 3.4. Accordingly, ACE gene polymorphism may be associated with morbidity from CAD in Japanese living in northern Japan as has been noted in Caucasians, despite the lower frequencies of the D-allele in the Japanese population. (Jpn Heart J 36: 557-564, 1995)
\end{abstract}

Key words: Angiotensin I-converting enzyme Insertion/deletion polymorphism Myocardial infarction Risk factors

From the First Department of Internal Medicine, Yamagata University School of Medicine, Yamagata, Japan.

Address for correspondence: Hitonobu Tomoike, M.D., The First Department of Internal Medicine, Yamagata University School of Medicine, 2-2-2 lida-Nishi, Yamagata 990-23, Japan.

This study was supported in part by grants-in-aid for Scientific Research (No. 06274202, 06454284) from the Ministry of Education, Science and Culture, Japan, grants for Rescarch on Cardiovascular Disease from the Ministry of Health and Welfare, Japan, and a grant from Yamagata prefecture.

Received for publication May 15, 1995.

Accepted June 21, 1995. 
YAMBIEN and colleagues described the rationale of DNA-typing to 1 determine a risk profile for cardiovascular disease. ${ }^{1,2)}$ With regard to the insertion (I) / deletion (D) DNA polymorphism of the gene coding human angiotensin converting enzyme (ACE), the frequency of deletion polymorphism or the D-allele was significantly greater in patients with myocardial infarction than in controls. ${ }^{1)}$ The DD genotype is associated with higher concentrations of circulating ACE. ${ }^{3,4)}$ These findings require attention, since administration of an ACE inhibitor to patients with asymptomatic left ventricular dysfunction decreased the risk of development of heart failure and also the risk of a recurrent myocardial infarction. ${ }^{5)}$ Association of polymorphism with a parental history of fatal myocardial infarction shows the importance of the genetic variation in the ACE locus. ${ }^{2)}$ The increased risk for myocardial infarction in patients with the deletion polymorphism seems to be independent of other risk factors, particularly the usual lipid variables. ") However, the risk profile for coronary artery disease differs with the country. ${ }^{6}$ In China, the primary risk factors are mainly tobacco use and hypertension; in Japan, tobacco use remains the most important and in Germany, $38 \%$ of 6025 persons had 3 or more risk factors, especially obesity and hyperlipidemia. ${ }^{7}$ As there are ethnic differences in these risk factors and in morbidity and mortality for ischemic heart disease, ${ }^{8)}$ studies on non-Caucasians have to be done. We report here an association between ACE-gene polymorphism and risk factors for coronary artery disease in Japanese living in northern Japan.

\section{Materials and Methods}

Subjects: Ninety consecutive Japanese patients (mean \pm SD age, $63 \pm 10$ years) referred for cardiac catheterization to the First Department of Internal Medicine, Yamagata University Hospital and diagnosed as cases of myocardial infarction or angina pectoris were enrolled in a study on coronary artery disease. Sixty of the 90 patients had myocardial infarction (MI) and 30 were diagnosed as having angina pectoris (AP). Data on another 19 patients ( $36 \pm 4$ years) with myocardial

Table 1. Distribution of ACE Genotypes and Frequency of D Allele in Non-coronary Subjects

\begin{tabular}{lccccc}
\hline & & \multicolumn{3}{c}{ ACE-genotypes } & \\
\cline { 5 - 6 } Groups & Age & DD & ID & II & D Allele \\
\hline Subjects under 40 y & $29 \pm 6$ & 1 & 12 & 11 & 0.29 \\
Subjects over 56 y & $64 \pm 5$ & 1 & 12 & 19 & 0.22 \\
Patients & $61 \pm 6$ & 4 & 14 & 19 & 0.28 \\
\hline Total & & 6 & 38 & 49 & 0.27 \\
\hline
\end{tabular}

The group of patients includes bronchial asthma, sarcoidosis, lung cancer and chest pain syndrome. $\mathrm{DD}=$ deletion/deletion; $\mathrm{ID}=$ insertion/deletion; $\mathrm{II}=$ insertion/insertion. 
infarction (young MI), were collected consecutively from lists of cardiac catheterization subjects in three cardiovascular centers (Yamagata University Hospital, Yamagata Prefectural Central Hospital and Ishinomaki Red Cross Hospital). In all cases, the parents of each patient were residents of the Yamagata area or the northern part of Japan. Since the age was different between MI or AP and young MI, the young MI group was analyzed separately from the coronary artery disease group $(\mathrm{CAD})$ which included both $\mathrm{MI}$ and $\mathrm{AP}$.

Non-coronary subjects included 1) residents under age forty years $(n=24$, $29 \pm 6$ years), 2) residents over age 56 years ( $n=32,64 \pm 5$ years), 3) patients with no cardiac disease $(n=37,61 \pm 6$ years), but who had bronchial asthma, lung cancer, sarcoidosis or chest pain syndrome (Table I). None had a history of coronary artery disease and electrocardiograms during rest and physical exercise were normal. Chest pain syndrome was diagnosed in cases with normal coronary angiograms both at rest and during an ergonovine study. Patients with hypertrophic or dilated cardiomyopathy were excluded from the group of non-cardiac diseases. ${ }^{9,10}$ All subjects were the offspring of parents who were residents of the Yamagata area or of the northern part of Japan. Informed consent was obtained from the subjects.

DNA extraction and ACE gene polymorphism: DNA was prepared from leukocytes in peripheral blood using Isoquick kits (Microprobe Corporation, Bothell, WA, USA). Before initiation of the polymerase chain reaction (PCR), DNA concentrations were measured by absorbance at $260 \mathrm{~nm}$ and the DNAs were run on $0.4 \%$ agarose gels. These DNAs were used as the template for PCR amplification of the intron 16 of the ACE gene, using two primers designed to encompass the polymorphic region; ${ }^{11}$ sense oligo 5'CTGGAGACCACTCGCATCCTTTCT3' and anti-sense oligo: 5'GATGTGGCCATCACATTCGTCAGAT3'. The PCR reaction contained DNA template $100 \mu \mathrm{g} / \mathrm{m} l, 30 \mathrm{pmol}$ of each primer, $200 \mu \mathrm{mol}$ of dNTPs, 1.25 units of AmpliTaq DNA polymerase (Perkin Elmer Cetus, Norwalk, CT, USA), and $2 \mathrm{mM} \mathrm{MgCl} 2$. DNA was amplified for 30 cycles with denaturation at $94^{\circ} \mathrm{C}$ for $1 \mathrm{~min}$, annealing at $58^{\circ} \mathrm{C}$ for 1 min, extension at $72^{\circ} \mathrm{C}$ for $2 \mathrm{~min}$, and a final extension time of 5 min using a PC700 thermal cycler (Astec Corp., Fukuoka, Japan). PCR products were analyzed on ethidium bromide-stained agarose gel electrophoresis for allele identification, where a $190 \mathrm{bp}$ fragment (D) indicates the absence of the insertion and a $490 \mathrm{bp}$ fragment (I) presence of the insertion. ${ }^{11)}$

Evaluation of coronary risk factors: Routine laboratory tests and coronary risk factors were evaluated. Hyperlipidemia was defined as a total cholesterol value over $220 \mathrm{mg} / \mathrm{d} l$ prior to ingestion of a meal. ${ }^{12)}$ Hypertension met the WHO criteria of over $160 \mathrm{mmHg}$ in systole or $90 \mathrm{mmHg}$ in diastole. ${ }^{13)}$ Diabetes mellitus was diagnosed based on the results of a $75 \mathrm{~g}$ oral glucose tolerance test. ${ }^{14}$ Use of 
tobacco was considered a significant risk factor at over 200 points on the Brinkman Index. ${ }^{15)}$ We used the standard for our hospital to diagnose hyperuricemia where over $8.7 \mathrm{mg} / \mathrm{d} l$ in men and over $5.4 \mathrm{mg} / \mathrm{d} l$ in women is considered to be significantly elevated.

Statistics: Numerical data are presented as means \pm SD. Differences in the distribution of the DD, ID, or II genotypes between the two groups of subjects were determined by multiple group contingency table analysis. Difference in the distribution of $\mathrm{D}$ and $\mathrm{I}$ alleles between groups was tested using the chi-square test. To determine independency of ACE gene polymorphism from other coronary risk factors, we used the chi-square test. $P$ values $<0.05$ were considered statistically significant.

\section{Results}

The frequencies of the $\mathrm{D}$ and I alleles of the ACE gene in our non-coronary subjects were 0.27 and 0.73 , respectively. The frequency of the DD genotype in the non-coronary subjects was $6 \%$. Since we included several categories in noncoronary subjects, we separately calculated the frequencies of $\mathrm{D} / \mathrm{I}$ alleles and the genotype polymorphisms. Although the number was small in each category, a lower frequency of the $\mathrm{D}$-allele was clearly observed (Table I).

Table II. Distribution of ACE Genotypes and Frequency of D Allele in Patients with Coronary Artery Disease

\begin{tabular}{lccccc}
\hline & & \multicolumn{3}{c}{ ACE-genotypes } & \\
Groups & Age & DD & ID & II & D Allele \\
\hline MI & $64 \pm 10$ & 10 & 26 & 24 & 0.38 \\
AP & $61 \pm 7$ & 6 & 13 & 11 & 0.42 \\
Young MI & $38 \pm 6$ & 3 & 5 & 11 & 0.29 \\
\hline
\end{tabular}

Myocardial infarction was diagnosed according to the MONICA category ( $\mathrm{J}$ Clin Epidemiol 41: 105-114, 1988). $\mathrm{MI}=$ myocardial infarction; $\mathrm{AP}=$ angina pectoris.

Table III. $\%$ Incidence of Coronary Risk Factors in Individual ACE Genotype in Patients with CAD (Except Young MI)

\begin{tabular}{lcccc}
\hline & $\begin{array}{c}\text { DD } \\
(\%)\end{array}$ & $\begin{array}{c}\text { ID } \\
(\%)\end{array}$ & $\begin{array}{c}\text { II } \\
(\%)\end{array}$ & $\begin{array}{c}\text { Prevalence in CAD } \\
(\%)\end{array}$ \\
\hline Hypertension & 31 & 51 & 71 & 56 \\
Hypercholesterolemia & 50 & 36 & 46 & 42 \\
Smoking habit & 50 & 56 & 60 & 57 \\
Diabetes mellitus & 25 & 26 & 20 & 23 \\
Hyperuricemia & 13 & 18 & 17 & 17 \\
\hline
\end{tabular}

$\mathrm{CAD}=$ coronary artery disease. 
Table IV. Number of Risk Factors in ACE Genotype in Patients with CAD (Except Young MI)

\begin{tabular}{ccccc}
\hline Number of risk factors & DD & ID & II & $\chi^{2}$-test \\
$\sim 2$ & 12 & 27 & 26 & $\chi^{2}=0.31$, N.S. \\
$\geqq 3$ & 4 & 12 & 9 & \\
\hline
\end{tabular}

N.S.=not significant.

Table V. Distribution of ACE Genotypes in Patients with Hypertension, Hypercholesterolemia, and Smoking Habits in Coronary Artery Disease (Except Young MI)

\begin{tabular}{lcccc}
\hline & \multicolumn{4}{c}{ Genotypes } \\
\cline { 2 - 5 } & DD & ID & II & $\chi^{2}$-test \\
\hline Hypertension $(+)$ & 5 & 20 & 25 & $\chi^{2}=7.69, p<0.03$ \\
Hypertension $(-)$ & 11 & 19 & 10 & \\
\hline Hypercholesterolemia $(+)$ & 8 & 14 & 16 & $\chi^{2}=1.21$, N.S. \\
Hypercholesterolemia $(-)$ & 8 & 25 & 19 & \\
\hline Smoking habit $(+)$ & 9 & 22 & 21 & $\chi^{2}=0.25$, N.S. \\
Smoking habit $(-)$ & 7 & 17 & 13 & \\
\hline N.S. = not significant. & & & &
\end{tabular}

The frequency of distribution of ACE genotypes and D-allele in patients with coronary artery disease is summarized in Table II. The frequencies of the $\mathrm{D}$-allele and the DD genotype in patients with coronary artery disease did not differ between those with myocardial infarction and those with angina pectoris and were significantly higher than those in the non-coronary group (Table I) and younger patients with myocardial infarction (Table II). The odds ratio as an index of the relative risk of coronary artery disease (MI + AP) with the DD genotype to non-coronary subjects with the genotypes (II + ID) was 3.1.

The frequencies of risk factors with each ACE genotype are summarized in Table III. Independency of the ACE genotype from other risk factors was noted. The number of risk factors did not correlate with ACE genotypes (Table IV). As hypertension, hypercholesterolemia and tobacco use were present in 56, 42 and $57 \%$ of CAD subjects, respectively, the frequency of ACE polymorphisms was examined with the presence or absence of each risk factor (Table V). In patients ( $>40$ years) with $\mathrm{CAD}$, the DD genotype was significantly more prevalent in the absence of hypertension than in the presence of it. The relative risk of $\mathrm{CAD}$, except young MI, in normotensives with the DD genotype to (ID + II) was 3.4.

\section{Discussion}

Analysis by PGR of ACE insertion/deletion polymorphism in intron 16 demonstrated a statistically significant association of the DD genotype with coronary artery disease. The DD-genotype frequency in not only CAD but also non- 
CAD groups was, however, lower than noted in Caucasians ${ }^{1,2)}$ and in subjects living in the Osaka area, a central part of Japan ${ }^{16)}$ or in the Morioka area in northern Japan. ${ }^{17}$

Race-related variance in ACE-gene polymorphisms is known. In normal Caucasians, allele D frequency was $0.54-0.58$ and was similar in studies reported in Europe, ${ }^{17}$ Australia ${ }^{18)}$ and the United States, ${ }^{10)}$ while allele D frequency in black Americans was $0.61 .{ }^{19)}$ In Japanese, allele D-frequency tended to be low and was as variable as $0.27,0.33$, and 0.39 and 0.42 in the present study, Furuya et al, ${ }^{15}{ }^{15}$ Zhao et $a l,{ }^{20)}$ and Nakai et al, ${ }^{17)}$ respectively. Since we selected subjects whose parents were residents of the Yamagata area or the northern part of Japan, the present study suggests the importance of ethnic consideration in gene-association studies. The reason for such a wide variability of the D-allele among Japanese or among districts in Japan is unknown.

The D-allele or the DD-genotype is linked significantly to morbidity in cases of myocardial infarction ${ }^{1,16)}$ and also to the prevalence of restenosis. ${ }^{21)}$ However, this evidence has become controversial since recent studies have revealed the non-significant association of the $\mathrm{D}$-allele to morbidity in myocardial infarction ${ }^{22)}$ and to the prevalence of restenosis. ${ }^{23)}$ The Japanese have a lower incidence of ischemic heart disease, ${ }^{8 j}$ which corresponds in general to a lower frequency of the ACE DD-genotype among the Japanese. However, in populations with a lower frequency of the D-allele, patients with myocardial infarction showed a higher frequency of the D-allele in the Osaka study ${ }^{16}$ and in the present study. Accordingly, the association of the ACE genotype to the morbidity of coronary artery disease can be extended to Japanese.

In the present study, the D homozygote in CAD was more prevalent in the non-hypertensive group than in the hypertensive group, a finding which accords well with the original observation that the ACE/DD genotype is a risk factor for coronary artery disease in subjects normally considered to be at a low risk. There were no differences between genotypes for plasma cholesterol level, smoking habits or blood pressure in patients with CAD. Young MI showed similar frequencies of ACE gene polymorphism to those in NCS, a pattern which differed from that seen in subjects with $\mathrm{CAD}(p<0.05)$ along with a different risk profile noted in $\mathrm{CAD}$. Thus a study on a candidate gene that relates to the morbidity of coronary artery disease and known risk factors will need to be done to elucidate the pathogenesis and to prevent myocardial infarction.

\section{ACKNOWLEDGMENTS}

We thank Dr. K. Yokoyama, Yamagata Prefectural Central Hospital, Dr. Y. Takeishi, Ishinomaki Red Cross Hospital and Drs. K. Ikeda, T. Nagai, A. Fukui, N. 
Nozaki, O. Hirono, and R. Shiga, Yamagata University Hospital for discussion and assistance in collection of samples from subjects, S. Seino for excellent technical assistance, and A. Funaki and M. Arai for their valuable secretarial services.

\section{References}

1. Cambien F, Poirier O, Lecerf L, Evans A, Cambou JP, Arveiler D, Luc G, Bard J-M, Bara L, Ricard $\mathrm{S}$, Tiret L, Amouyel P, Alhenc-Gelas F, Soubrier F: Deletion polymorphism in the gene for angiotensin-converting enzyme is a potent risk factor for myocardial infarction. Nature 359: 641, 1992

2. Tiret L, Kee F, Poirier O, Nicaud V, Lecerf L, Evans A, Cambou J-P, Arveiler D, Luc G, Amouyel P, Cambien F: Deletion polymorphism in angiotensin-converting enzyme gene associated with parental history of myocardial infarction. Lancet 341: 991 , 1993

3. Rigat B, Hubert $C$, Alhenc-Gelas F, Cambien F, Corvol P, Soubrier F: An insertion/deletion polymorphism in the angiotensin I-converting enzyme gene accounting for half the variance of serum enzyme levels. J Clin Invest 86: 1343, 1990

4. Tiret L, Rigat B, Visvikis S, Breda C, Corvol P, Cambien F, Soubrier F: Evidence, from combined segregation and linkage analysis, that a variant of the angiotensin I converting enzyme (ACF) gene controls plasma ACE levels. Am J Hum Genet 51: 197, 1992

5. Pfeffer MA, Braunwald E, Moyé LA, Basta L, Brown EJ Jr, Cuddy TE, Davis BR, Geltman EM, Goldman S, Flaker GG et al: Effect of captopril on mortality and morbidity in patients with left ventricular dysfunction after myocardial infarction; results of the survival and ventricular enlargement trial. New Engl J Med 327: 669, 1992

6. Simons LA: Interrelations of lipids and lipoproteins with coronary artery disease mortality in 19 countries. Am J Cardiol. 57: 5G, 1986

7. Stehle G, Hinohara S, Gremer P, Feng Z, Bernhardt R, Dempfle CE, Goto Y, Seidel D, Heene DL, Schettler G: Risk factor patterns for coronary heart disease in China, Japan and Germany. Chin Med J 105: 356, 1992

8. Uemura K, Pisa Z: World Health Stat Q 41: 155, 1988

9. Raynolds MV, Bristow MR, Bush EW, Abraham WT, Lowes BD, Zisman LS, Taft CS, Perryman MB: Angiotensin-converting enzyme DD genotype in patients with ischaemic or idiopathic dilated cardiomyopathy. Lancet 342: 1073, 1993

10. Marian AJ, Yu Q-T, Workman R, Greve G, Roberts R: Angiotensin-converting enzyme polymorphism in hypertrophic cardiomyopathy and sudden cardiac death. Lancet 342: 1085, 1993

11. Rigat B, Hubert C, Corvol P, Soubrier F: PCR detection of the insertion/deletion polymorphism of the human angiotensin converting enzyme gene (DCP1) (dipeptidyl carboxypeptidase 1). Nucleic Acid Res 20: 1433, 1992

12. Reed DM, Strong JP, Resch J, Hayashi T: Serum lipids and lipoproteins as predictors of atherosclerosis; an autopsy study. Arteriosclerosis 9: 560, 1989

13. Report for a WHO Expert Committee: Arterial hypertension. WHO Technical Report Series, WHO Geneva. No. 628, 1978.

14. Report of a WHO Study Group: Diabetes mellitus, WHO Technical Report Series, WHO Geneva. No. $727,1985$.

15. Brinkman GL, Coastes EO Jr: The effect of bronchitis, smoking, and occupation on ventilation. Am Rev Resp Dis 87: 684, 1963

16. Zhao Y, Higashimori K, Higaki J, Kamitani A, Ohishi M, Katsuya T, Miki T, Mikami H, Minamino T, Ogihara T: Significance of deletion polymorphism of the angiotensin converting enzyme gene as a risk factor for myocardial infarction in Japanese. Hypertens Res 17: 55, 1994

17. Nakai K, Itoh C, Miura $Y$, Hotta K, Musha T, Itoh T, Miyakawa T, Iwasaki R, Hiramori K: Delecion polymorphism of the angiotensin I-converting enzyme gene is associated with serum ACE concentration and increased risk for CAD in the Japanese. Circulation 90: 2199, 1994

18. Zee RYL, Lou Y-K, Griffiths LR, Morris BJ: Association of a polymorphism of the angiotensin Iconverting enzyme gene with essential hypertension. Biochem Biophys Res Commun 184: 9, 1992 
19. Bloem LJ, Manatunaga AK, Boatright E, Pratt JH: Relation of race and polymorphism in the angiotensin I-converting enzyme gene to enzyme levels (abstr). Hypertension 22: 407, 1993

20. Furuya K, Yamaguchi E, Itoh A, Hizawa N, Ohnuma T, Kawakami Y, Konno N, Takahashi O: The insertion/deletion polymorphism of the angiotensin converting enzyme (ACE) gene and serum ACE levels in Japanese. Igakunoayumi (in Japanese) 168: 1099, 1994

21. Ohishi M, Fujii K, Minamino T, Higaki J, Kamitani A, Rakugi H, Zhao Y, Mikami H, Miki T, Ogihara T: A potent genetic risk factor for restenosis. Nature Genetics 5: 324, 1993

22. Lindpaintner K, Pfeffer MA, Kreutz R, Stampfer MJ, Grodstein F, LaMotte F, Buring J, Hennekens $\mathrm{CH}$ : A prospective evaluation of an angiotensin-converting-enzyme gene polymorphism and the risk of ischemic heart disease. N Engl J Med 332: 706, 1995

23. Samani NJ, Martin DS, Brack M, Cullen J, Chauhan A, Lodwick D, Harley A, Swales JD, de Bone DP, Gershlick AH: Insertion/deletion polymorphism in the angiotensin converting enzyme gene and risk of restenosis after coronary angioplasty. Lancet 345: 1013, 1995 